\title{
The main directions of the development of snowmobiles in the Russian Federation
}

\author{
Aleksey S. Diakov ${ }^{1, *}$, Aleksey V. Pozdeev², and Vyacheslav V. Novikov ${ }^{2}$ \\ ${ }^{1}$ Bauman Moscow State Technical University, Baumanskaya 2-ya, 5/1, Moscow, Russia, 105005 \\ ${ }^{2}$ Volgograd State Technical University, Russia, Lenin, 28, Volgograd, Russia, 400005
}

\begin{abstract}
This article describes such constructive units of domestic snowmobiles as gasoline engines, layout schemes and types of platforms, caterpillar propulsions unit and caterpillars, front and rear suspension, steering, transmission and brake systems.
\end{abstract}

From the analysis of technical characteristics of modern domestic snowmobiles it is possible to mark out the following characteristic design features of 7 main units of this type of winter cars [1-22].

\section{Power unit}

At the moment the most widespread have petrol carburettor two-stroke units one-and twocylinder, row arrangement of cylinders (Fig. 1). Diesel engines in the domestic snowmobiles are not set because of their heavy weight and difficult to start at low temperatures.

The tendency to use petrol engines, as well as the peculiarities of their design, can be explained mainly by the experience of manufacturers in the application of a particular type of engine, because many manufacturers have extensive experience in the production of motorcycles and therefore use typical motorcycle engines and their snowmobiles.

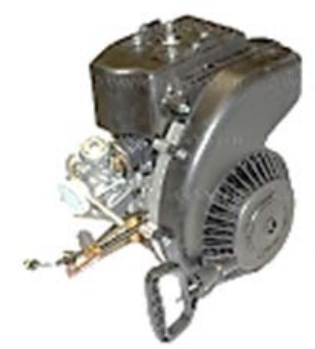

$R M Z-250$

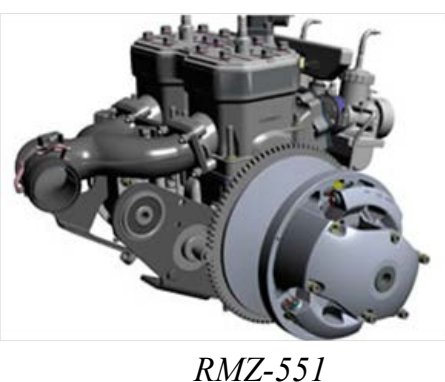

RMZ-551

Fig. 1. Gasoline single-cylinder and two-cylinder two-stroke engines RMZ with carburetor fuel supply system

\footnotetext{
*Corresponding author: diakov57@,1ist.ru
} 
Despite the active promotion of models with four-stroke engines, two-stroke models have the following advantages: low weight; simplicity of design; high maintainability in the absence of services; possibility of manual start.

Pros of four-stroke engines: low fuel consumption; greater common resource; low noise; environmental friendliness. The engine power, and therefore their volume, and the number of cylinders, depend on the class and purpose of snowmobiles (utilitarian, tourist, children, adolescents, etc.). Accordingly, the engine volumes are also different: from 200 to $800 \mathrm{~cm} 3$ - for single- and double-cylinder units, realizing from 6.5 to $67 \mathrm{hp}$.

Until recently, all snowmobiles were equipped with only a carburetor power system. In the 90 s of the last century, an alternative appeared - fuel injection, which has recently gained wide acceptance. The injection is used both on two-stroke, and on four-stroke engines. Advantages of injection: high efficiency; stability of the fuel mixture, which avoids many problems with the engine; environmentally friendly. But there is a disadvantage, which is reduced to the complexity of injection and its non-repairable in the field. Therefore, carburettors will remain in demand for a long time by those consumers who use snowmobiles in the harsh conditions of the taiga and the far North, relying only on themselves.

Currently, the most widely the power supply system - carburetor for each cylinder. But, despite all the advantages of carburetors, domestic manufacturers are gradually beginning to use the system with fuel injection. For example, in 2018, JSC "Russian mechanics" began to produce a new two-cylinder two-stroke engine $R M S 551 i$ with distributed fuel injection capacity of $65 \mathrm{hp}$. Compared with the $P M Z-551$ engine with carburetor power supply system, this engine provides power growth by $8 \%$, reduces operating fuel consumption by $20 \%$ and reduces harmful emissions. In the engine RMS 551i it is possible to start it from the emergency starter even with a fully discharged battery (Fig. 2).

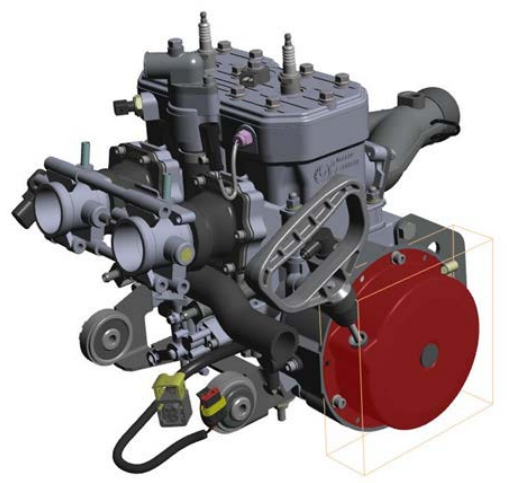

Fig. 2. RMS 551i engine with fuel injection and emergency manual start mechanism.

Some manufacturers use three- and four-cylinder engines. For example, the company "Husky" on a snowmobile "Snegomaks", which has a cabin, sets a three-cylinder four-stroke engine with a capacity of $993 \mathrm{~cm} 3$ and a power of $53 \mathrm{hp}$. «Ural-Motors», «Motors Vasiliya Pryadeina», NGO «Transport», use four-cylinder automobile engines, which have even more volume and power. Models with these engines have a clearly pronounced utilitarian orientation - in fact, they are small trucks with caterpillar propulsion and controlled skis, which have the typical architecture and dimensions of snowmobiles.

The engines used on domestic snowmobiles mainly have forced air cooling, but with the increase in power, a liquid cooling system with the installation of radiators begins to be introduced. The choice of type of cooling depends on the expected operating conditions.

Air-cooled engines are lighter and simpler, but sometimes they may be prone to overheating. 
The liquid cooling system provides a more stable temperature regime. But it has a drawback. The radiator of liquid cooling on snowmobiles, in the vast majority of cases, is cooled not by air, but by snow flying from under the caterpillar. The probability of damage falling under the caterpillar objects, stumps, etc. Further movement with such damage is impossible. In addition, the liquid cooling system limits the possibility of prolonged movement over coatings that are free of loose snow - on ice and sloping roads. Since the radiator is not cooled by snow, there is overheating.

The engine start system can be either using an electric starter from the battery, or manual from the magneto.

The engine lubrication system can be mixed or separate. But the separate is becoming more preferable, providing better lubrication conditions and lower oil consumption.

As the review has shown, there are practically no electric power plants on domestic snowmobiles. Probably, this is due to the poor ratio of the masses of the machine and the batteries and the lack of a developed system for recharging them in the field. However, the development of snowmobiles with electric drive has already begun. For example, JSC "Russian mechanics" is already testing prototypes of electric quadrocycles, on the basis of which they plan to develop snowmobiles with electric traction.

\section{Layout schemes and types of platforms}

In general, snowmobiles can be divided into two schemes: "two caterpillars - one ski" and "one caterpillar - two skis." The first scheme is mainly used for the utilitarian class of snowmobiles, which require a large area of the supporting surface. The second scheme is simpler, which makes the snowmobile easier and makes it more agile. Therefore, this scheme is currently the most common.

The layout scheme largely determines the shape of the platform on which all the main components of the snowmobile are mounted. The platform has a three-dimensional design and is usually made of steel and welded from a curved sheet profile (Fig. 3). Recently, aluminum alloys began to be used instead of steel for the manufacture of lighter platforms.

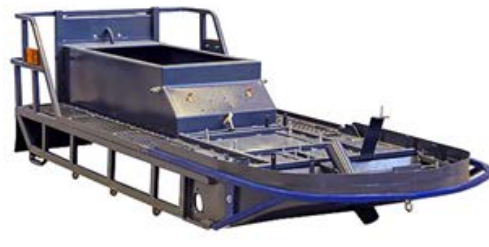

Buran

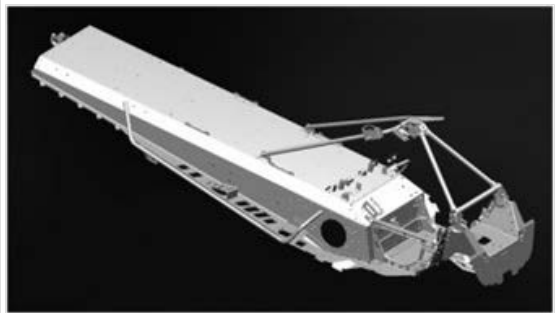

Taiga $551 R$

Fig. 3. Platforms for two-track and single-track snowmobiles "Buran" and "Taiga"

Some features of the aluminum platform Taiga $551 R$ :

- The front part of the platform is made by injection molding and is connected to the rest of the elements mainly by means of riveted joints and a minimum number of welded joints, which provides high resistance under shock and vibration loads;

- bevels at the top of the tunnel platform and the pyramidal design of the front part (for fastening the rudder support) provide additional rigidity of the entire structure.

Regardless of the overall layout, the engine is usually located at the front, which allows for better heating of the driver and passenger. At the same time, they try to equalize the weight of the snowmobile as far as possible relative to its longitudinal axis of symmetry. 
For this, for example, on a snowmobile Taiga $551 \mathrm{R}$ gearbox is installed in the engine compartment to the right of the engine (in the direction of travel) (Fig. 4).

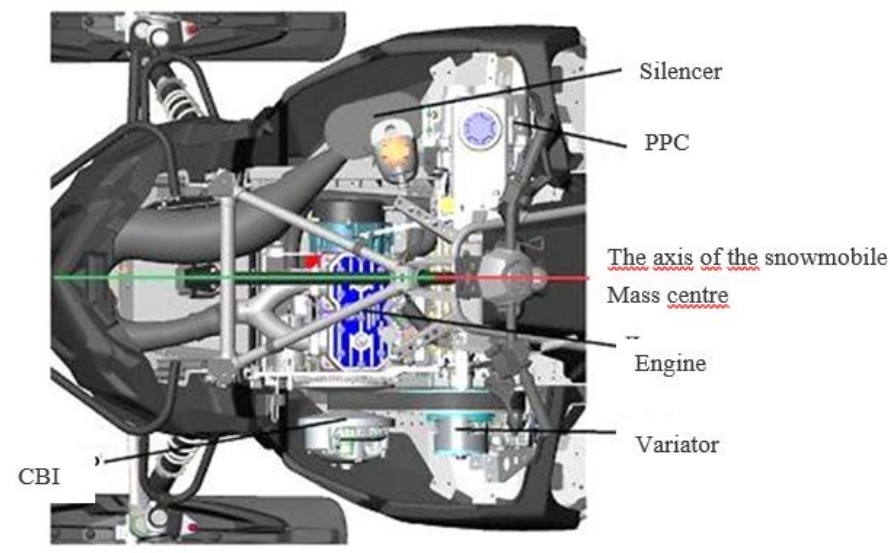

Fig. 4. Layout of the power part of the Taiga $551 R$ snowmobile drive.

They also strive to make a uniform weighting also relative to the transverse axis of the snowmobile. For this purpose, the battery is located under the passenger seat, and the luggage compartment is made from behind.

For example, on the military snowmobile AC-1, created on the basis of the Taiga Patrol 551 SVT model, there is an increased trunk that allows to install two metal cans of 20 liters each, and also to fasten two pairs of skis, a grenade launcher, an AK-74 assault rifle and SVD rifle (Fig. 5).
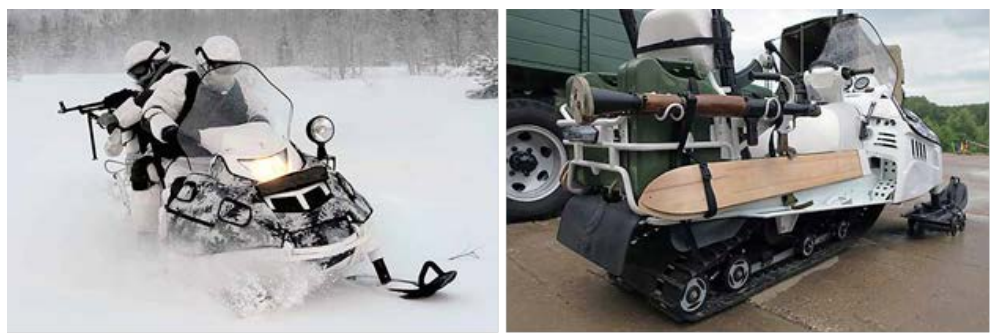

Fig. 5. Army snowmobile AC-1 based on the «Taiga Patrol 551 SVT» model.

\section{Caterpillar propulsions}

As the caterpillar propulsion unit of snowmobiles usually use a roller-skliz system, which includes a combination of guides, the basic and supporting skating rinks is, as well as two longitudinal skliz are removable plastic "skis" that are supported by the main length of the track support part (Fig. 6).

Sklizes slide on metal plates, located on the caterpillar. As a lubricant in this pair of slip is used snow. The driver of the snowmobile should keep this in mind and make sure that the snow crawls periodically in the caterpillar, moving along snowless covers - ice and densely rolled roads. Sometimes it is necessary to specially throw snow into the caterpillar or even splash water. Otherwise, the sklizes will begin to warm, wear out intensively - until melting. 


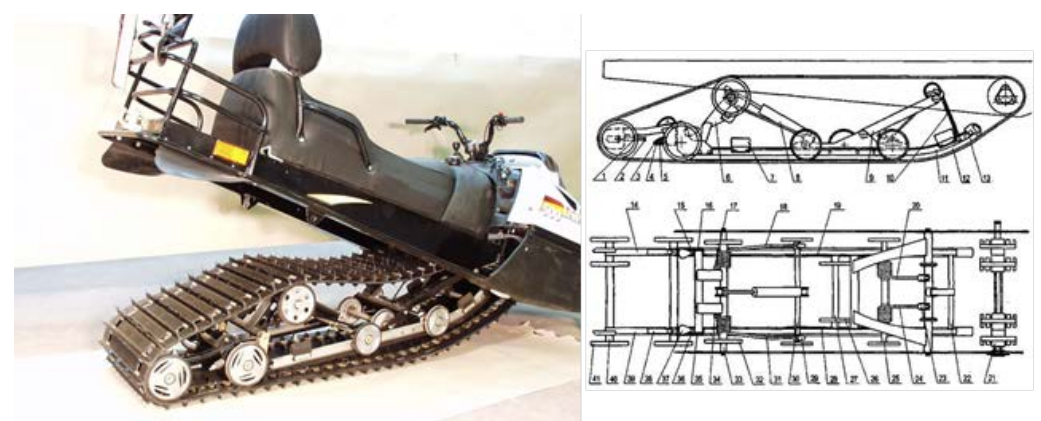

Fig. 6. Caterpillar propulsion system with roller-skliz system of snowmobile "Taiga 500"

The support system is used only on one support rollers on separate models of snowmobiles, such as "Buran", MWP-500, Alpina Sherpa. This system has the obvious advantage - such snowmobiles can confidently move on snowless surfaces: ice and hardpacked roads (Fig. 7).

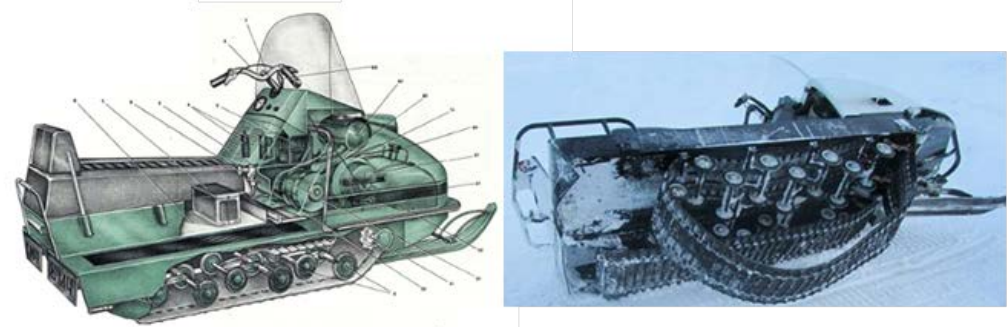

Fig. 7. Caterpillar propulsion with a support-roller system of the snowmobile "Buran"

The design of the snowmobile caterpillar is an all-in-one rubber band reinforced with a synthetic cord. On the outside, it is equipped with grousers, and the inside is smooth. Through the entire length of the caterpillar belt, two rows of holes are provided, reinforced with metal plates. Distinguish two natures of gearing: through windows and spindle (fig. 8). At spindle gearing on an inner surface of a tape there are toothed ledges.

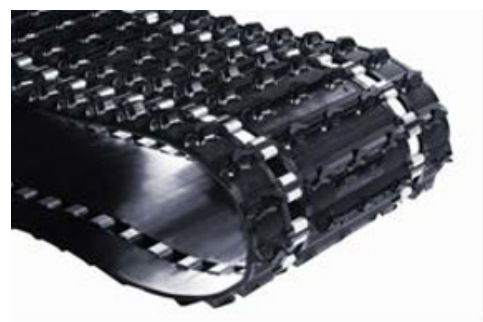

Buran

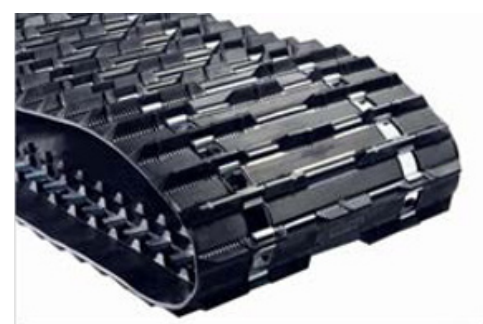

Taiga 600

Fig. 8. Caterpillars with gearing through windows and spindle gearing for snowmobiles Buran and Taiga 600

At design of a snowmobile depending on its assignment designers have an opportunity to pick up length and width of a caterpillar and height of the grouser. At the same time height of the grouser depends on engine power. The technical specification on the stated above caterpillars is given below and in tab. 1 . 
Table 1. Specifications of tracks of Buran and Taiga 600 models

\begin{tabular}{|l|l|l|}
\hline \multicolumn{1}{|c|}{ Snowmobile models } & \multicolumn{1}{|c|}{ Buran } & \multicolumn{1}{c|}{ Taiga 600 } \\
\hline Type of engagement & Through the windows & Spindle \\
Number of steps & 73 & 62 \\
Caterpillar weight, kg & 19 & 35 \\
Dimensions (Length x Width x Pitch), mm & $3686 \times 380 \times 50,5$ & $3937 \times 600 \times 63,5$ \\
(inches) & $(145 \times 15 \times 1,99)$ & $(155 \times 24 \times 2,5)$ \\
Height of the grouser, mm (inches) & $17,5(0,69)$ & $22,5(0,89)$ \\
The list of models of the equipment which the & Buran 4TD, Buran SB- & PATRUL 550 SWT, BARS, \\
caterpillar approaches & Taiga classic 11, \\
& Buran SB-640MD, & Taiga St-500D \\
& Buran SB 640 AD & PATRUL 551 SWT \\
\hline
\end{tabular}

The standard caterpillar for the snowmobile "Buran" (long base) has a standard "herringbone" pattern, which provides high cross-country ability for various types of snow cover. Standard caterpillar for snowmobiles "Taiga-Patrol" and "Leopard" has a symmetrical pattern of the grouser that allows to reduce side sliding and doesn't limit driving direction. The increased width of $60 \mathrm{~cm}$ and the strengthened reinforcement ribs allow to make traction properties higher.

Manufacturers of snowmobiles have made sure that the caterpillar has ceased to be a consumable element. Its resource under normal operation is not less than the resource of the snowmobile itself. However, if the caterpillar is damaged, a breakage is possible. Repair in this case is not possible, only the replacement of the caterpillar.

An indispensable condition for the continuous operation of the caterpillar is regular monitoring of its tension and alignment. The holes in the caterpillar are necessary for engaging the teeth of the driving sprocket. It is the ingress of foreign objects into these holes - the main cause of damages and cracks in the caterpillar. Metal plates that strengthen the holes, and perform one more function - they form a pair of slip with sklizes.

The choice of caterpillar parameters and the degree of its loading greatly affect the balance of snowmobile qualities at the stage of its design. Among them, the most important are 3 parameters: the width of the caterpillar; the length of the caterpillar; weight distribution, i.e. the distribution of the total mass of the snowmobile between skis and the caterpillar.

Reducing the width of the caterpillar increases the controllability and maneuverability, reduces the snowmobile's dependence on longitudinal unevenness, and its increase improves the patency. Currently, most single-track snowmobiles are available with a standard 15 inch $(381 \mathrm{~mm})$ track width, or with a wide caterpillar (widetrak) width of 20 inches $(508 \mathrm{~mm})$. Recently, the ultra-wide caterpillar is becoming popular - 24 inches (610 $\mathrm{mm}$ ). Using ultra-wide caterpillar allows you to come close to cross-country to two-track snowmobiles.

Wide tracks until recently were a lot of utilitarian snowmobiles. But recently on the market there were intermediate models that combine the comfort of tourist snowmobiles with the presence of a wide, and even ultra-wide, tracks.

Reducing the length of the caterpillar contributes to improved handling and maneuverability, and its increase improves cross-country ability. In the technical data of snowmobiles it is always given the length of its full circle, as a rule, it is $3000-4000 \mathrm{~mm}$. The supporting surface of the track does not exceed a third of this length.

Increase the burden on the ski, improves the handling. By going this route in the design of cross and touring models, for which the permeability in deep snow is a secondary quality. Increasing the load on the caterpillar together with increasing its size shifts the priority in the direction of patency. 


\section{Suspension bracket}

Suspension of the front and rear parts of the snowmobile largely depends on the layout scheme.

At two-caterpillar snowmobiles the suspender of caterpillar propulsions unit has the balancer sprung design expected depreciation of small roughnesses and adaptation of a caterpillar to a landscape.

In single-track snowmobiles, the caterpillar propulsion suspension is calculated for effective energy retraction when driving at high speeds, when jumping. Its obligatory element are shock absorbers. The main characteristic of this suspension is its stroke. Usually it is $200-300 \mathrm{~mm}$, on individual models of mountain snowmobiles it can reach 400 mm.

Springs for torsion, cylindrical springs and torsion shafts are used as elastic elements for suspension of crawler propulsion elements. As shock absorbers - hydraulic and gas-filled shock absorbers, including the ability to adjust the static position depending on the degree of loading.

For example, the rear suspension of the "TAYGA 550 Patrul SWT" snowmobile is adjustable, it provides a stroke of $190 \mathrm{~mm}$ and has a breaking heel that heats, which prevents snagging in the snow when reversing (Fig. 9).

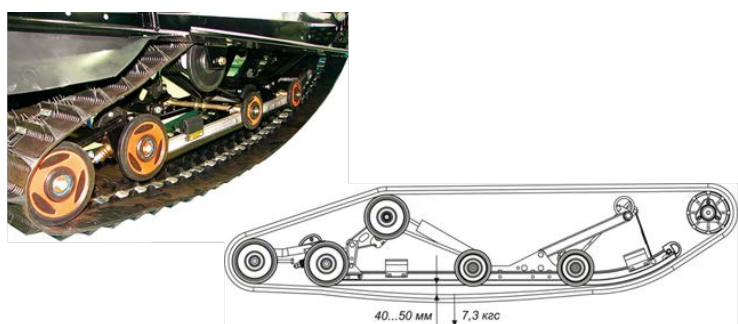

Fig. 9. Rear suspension of the snowmobile "TAYGA 550 Patrul SWT"

Currently, the most common are two types of front suspension: telescopic and doublelever. The first type is more compact, and the second type provides larger strokes (Fig. 10).

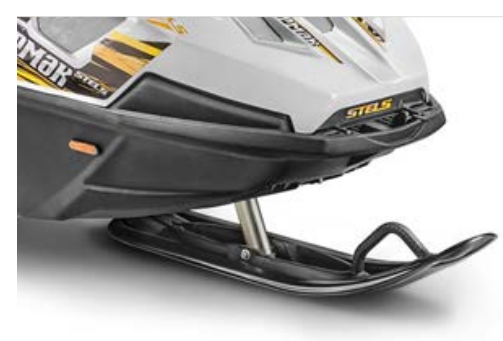

Stels «Ermak»

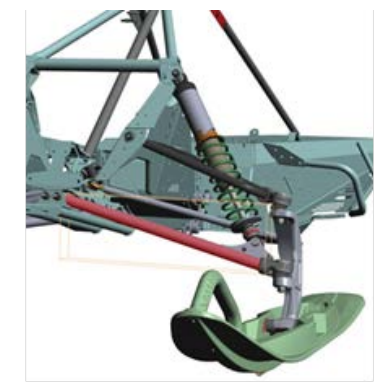

RMS 551i TOUR

Fig. 10. Front telescopic and lever suspension of snowmobiles Stels "Ermak" and RMS 551i TOUR

\section{Steering}

Snowmobile is mostly used by the steering of a motorcycle type, including the latest models - with the position adjustment (Fig. 11). On heavy snowmobiles it is possible to install a hydraulic or electric power steering. 

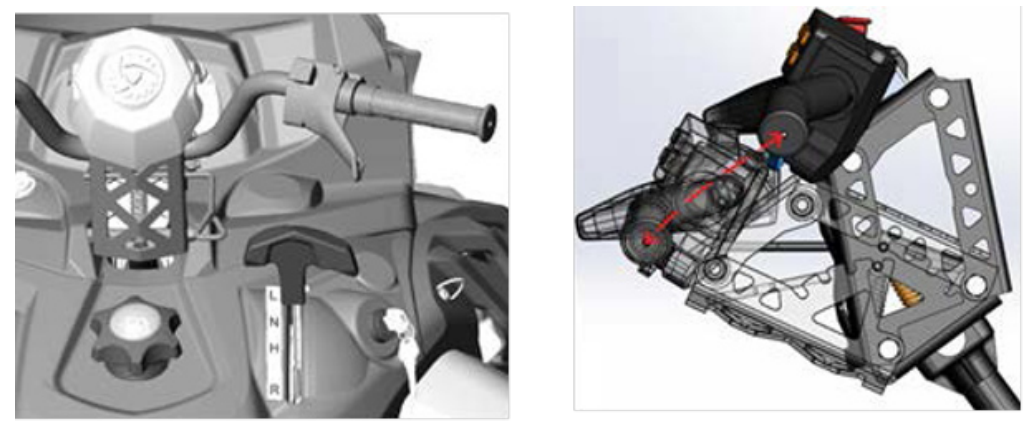

Fig. 11. Steering with a mechanism for adjusting the position of the helm of a snowmobile $R M S 551 i$ TOUR

It is known that in comparison with the scheme "two caterpillars - one ski" snowmobile with one caterpillar and two skis has better handling. In turn, the controllability of such a snowmobile is influenced by the track of skis, the size of which in most modern snowmobiles depends more on the design of the front suspension. For models with candle suspension it is about $950 \mathrm{~mm}$, for models with lever-about $1050 \mathrm{~mm}$. These values are an engineering compromise, since each type of snowmobile there are factors limiting its excessive reduction or increase.

As a general rule, increasing the track improves the stability and manageability of the snowmobile. But at the same time, and limits the ability to actively control the snowmobile - it becomes more difficult for the driver to tilt the snowmobile with its own weight while passing through turns, while moving across slopes. On many models it is possible to adjust the gauge depending on the owner's preferences.

Since, with a single track system, all three support points are substantially spaced apart at the corners of the triangle, this makes it possible to equip the snowmobile with longstroke effective suspensions.

\section{Transmission}

The basis of the transmission of any snowmobile is a V-belt variator, which serves as a clutch and gear ratios while driving (Fig. 12).

After the variator, the torque can be transmitted to the driving sprocket of the caterpillar in two ways: either through an additional reducer; or directly. Almost all utilitarian and tourist snowmobiles have a separate gearbox, providing the possibility of reverse gear and low gear. The low gear is used at the movement under trying conditions (deep chubby snow, the movement in long rises) and also at the movement with the loaded trailer.

On sports snowmobiles the low gear isn't necessary and the reducer on them is used only for inclusion of back run.

The reverse gear is included in a basic equipment practically of all snowmobiles.

The belt on the snowmobile is an expendable material and the presence of a spare belt is an indispensable condition for operation. The average conditional life of the belt during its normal operation is $500 \ldots 1000 \mathrm{~km}$. Although it can be rendered unusable and for a few kilometers - by inexperience. On the contrary, under good operating conditions, a quality belt can last several thousand kilometers. 

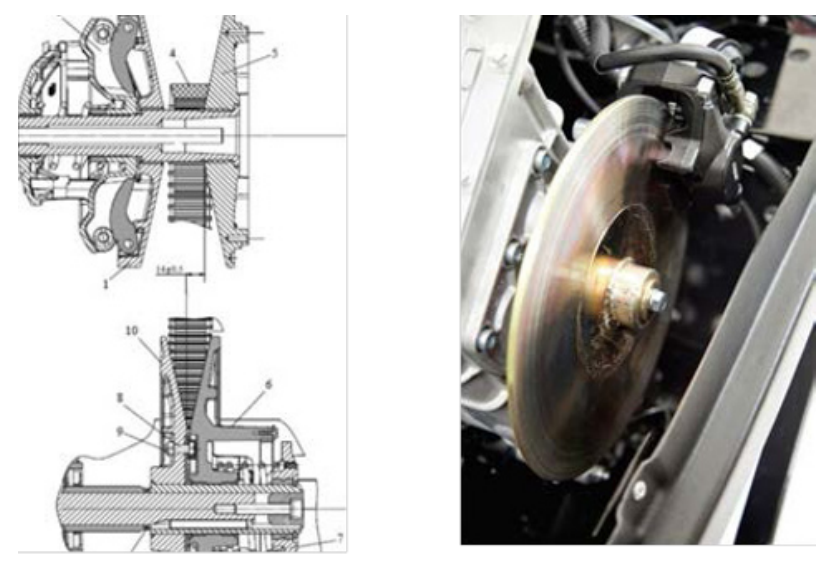

Fig. 12. Variator and hydraulic drive of the disc brake of the snowmobile «TAYGA 550 Patrul SWT»

\section{Brake systems}

Virtually all snowmobiles have disc brake mechanisms with hydraulic drive (Fig. 12).

\section{Summary}

The analysis of designs of domestic snowmobiles showed that their development goes on the way of improvement of the main units for the purpose of improvement of mass technical characteristics and operational properties.

Among the engines, three - and four-cylinder four-stroke petrol engines are the most common, providing lower fuel consumption, longer life, low noise and environmentally friendly exhaust. But also more simple in operation two-stroke motors remain in demand.

Layout schemes depend on the type of snowmobile, but gradually begin to produce more winter cars with a simpler layout: "one caterpillar - two skis." In this case, regardless of the layout of the main material for the manufacture of lighter snowmobile platforms are aluminum alloys.

The caterpillar propulsion unit of domestic snowmobiles generally is simpler on a design roller-skliz system. But there are also basic systems on one skating rinks which are applied, for example, on snowmobiles "Buran", MVP-500 and Alpina Sherpa. The resource of the work of caterpillars is already comparable with the life of a snowmobile, previously it was an expendable element. At the same time for mountain snowmobiles there is a tendency to decrease the length and width of the track, which gives an improvement in controllability, and for utilitarian and tourist snowmobiles, wider and longer caterpillars are used to increase their patency.

Suspension elements are torsion springs, coil springs and torsion shafts, as well as hydraulic and gas-filled shock absorbers with the ability to adjust the static position from the load. The most common are two types of front suspension - telescopic and double-lever. The first type is more compact, and the second type provides a large stroke.

Steering is used by a motorcycle type with position adjustment and the installation of a hydraulic or electric power steering. Individual adjustment of the ski track is also possible.

The transmission is based on a V-belt variator, which also acts as a clutch, and a gearbox for reducing the speed and reverse of the driving sprocket. But on sports 
snowmobiles, lower gears are not installed, but only a rear speed reducer is used. The belt life corresponds to a run up to $1000 \mathrm{~km}$.

Brake systems are installed discs with a hydraulic drive.

As a result of such improvements, domestic snowmobiles come very close to foreign ones, but their cost remains much lower.

It should be noted that the this work was carried out at the Bauman Moscow State Technical University, with financial support from the government in the face of the Russian Ministry of Education under the project: №14.577.21.0272. (Identification number: RFMEFI57717X0272)

\section{References}

1. Derunov, G.P. Mashinnaya tyaga saney. Istoriya russkogo snegokhoda / G.P. Derunov, A.M. Kirindas, I.V. Ksenofontov. - Rybinsk: Mediarost, 2011. - 351 s.

2. Petrova, M.S. Otsenka konkurentosposobnosti otechestvennykh snegokhodov i puti yeye povysheniya / M.S. Petrova, I.I. Itskovich // Vestnik Rybinskoy gosudarstvennoy aviatsionnoy tekhnologicheskoy akademii im. P.A. Solov'yeva. 2013. № 1 (24). S. 302-306.

3. Petukhov, M.YU. Problemy ekspluatatsii snegokhodov importnogo proizvodstva $v$ ekstremal'nykh usloviyakh / M.YU. Petukhov, A.M. Shcheludyakov // Zhurnal: Modernizatsiya i nauchnyye issledovaniya $\mathrm{v}$ transportnom komplekse. - 2013. - № 1. - S. 323-328.

4. Suleymenov, T.B. Kardazhyrgishtiң me乡gerik shayġy aspasyn zhetildiru / Suleymenov T.B., Sarzhanov D.K., Abishev K.K., Yesenzhol D.K. // Nauchnyy zhurnal «Vestnik YENU im. L.N. Gumileva». № 6 (109). - Astana: Izd-vo YENU im. L.N. Gumileva, 2015. - S. 228-231.

5. Abishev, K.K. K voprosu sovershenstvovaniya khodovoy chasti snegokhodov / K.K. Abishev, D.K. Sarzhanov, O.T. Balabayev, D.K. Yesenzhol // Mezhdunarodnyy zhurnal prikladnykh i fundamental'nykh issledovaniy. 2016. № 5-5. S. 704-708.

6. Filippov, E.I. Povysheniye effektivnosti ekspluatatsii snegokhoda «Buran» $v$ usloviyakh kraynego severa / E.I. Filippov, R.D. Pastukhova // Sovremennyye tendentsii razvitiya nauki i tekhnologiy. 2017. № 2-3. S. 52-53.

7. Lebedeva, A.I. Osnovnyye napravleniya realizatsii politiki importozameshcheniya na primere deyatel'nosti AO «Russkaya mekhanika» / Lebedeva A.I., T.V. Smirnova // V sbornike: Strukturnyye izmeneniya v ekonomike Rossii v usloviyakh torgovoekonomicheskikh sanktsiy i politiki importozameshcheniya. Sbornik nauchnykh trudov po itogam Vserossiyskoy nauchno-prakticheskoy konferentsii. 2017. S. 59-62.

8. Analiz rynka snegokhodov $v$ Rossii [Elektronnyy resurs]. - URL: http://www.prnews.ru/topic/analiz-rynka-snegohodov-v-rossii.

9. Snegokhody STELS. - Rezhim dostupa: http://snegohod-stels.ru.

10. AO «Russkaya mekhanika» — proizvoditel' snegokhodov i motovezdekhodov (kvadrotsiklov) v g. Rybinske. - Rezhim dostupa: http://go-rm.ru.

11. Sravneniye snegokhodov Stels Moroz $i$ Buran [Elektronnyy resurs]. - URL: https://badmoto.ru/2017/10/16/russkaja-mehanika-buran-lider-vs-stels-moroz.

12. Novaya model' ot Russkoy Mekhaniki - snegokhod RMS 551I TOUR! [Elektronnyy resurs]. - URL: http://royal-auto.kz/blog/novaya-model-ot-russkoj-mehaniki--snegohod-rms-551i-tour.

13. P. m. 170153 Rossiyskaya Federatsiya, MPK B62M 27/02, B62D 55/06. Korpus snegokhoda / A.S. Afanas'yev, YU.V. Barshchevskiy, A.M. Zhogin; zayavitel' i patentoobladatel' OOO "VELOMOTORS". - №2016127430; zayavl. 07.07.2016; opubl. 17.04.2017, Byul. № 11. 
14. P. m. 170216 Rossiyskaya Federatsiya, MPK B62M 27/02, B62D 55/104. Podveska gusenitsy snegokhoda / R.S. Valeyev, A.V. Maslov, D.S. Tikhomirov; zayavitel' i patentoobladatel' AO "Russkaya mekhanika". - №2016140076; zayavl. 11.10.2016; opubl. 18.04.2017, Byul. № 11.

15. P. m. 168245 Rossiyskaya Federatsiya, MPK B62M 27/02, B62D 55/08. Podveska gusenitsy snegokhoda / A.M. Zhogin, A.N. Yermolayev, YU.V. Barshchevskiy, A.S. Afanas'yev; zayavitel' i patentoobladatel' OOO "VELOMOTORS". - №2016115130; zayavl. 20.04.2016; opubl. 25.01.2017, Byul. № 3.

16. P. m. 168762 Rossiyskaya Federatsiya, MPK B62D 55/00. Podveska gusenitsy snegokhoda / A.M. Zhogin, YU.V. Barshchevskiy; zayavitel' i patentoobladatel' OOO "VELOMOTORS". - №2016124097; zayavl. 17.06.2016; opubl. 17.02.2017, Byul. № 5.

17. P. m. 171267 Rossiyskaya Federatsiya, MPK F16H 1/00, B60K 17/06. Korobka pereklyucheniya peredach snegokhoda / A.M. Zhogin, A.N. Khmelevskiy; zayavitel' i patentoobladatel' OOO "VELOMOTORS". - №2016150874; zayavl. 23.12.2016; opubl. 26.05.2017, Byul. № 15.

18. P. m. 171285 Rossiyskaya Federatsiya, MPK B60K 15/063, B62D 63/04. Snegokhod / A.M. Zhogin, A.S. Afanas'yev; zayavitel' i patentoobladatel' OOO "VELOMOTORS". - №2016150875; zayavl. 23.12.2016; opubl. 29.05.2017, Byul. № 16.

19. P. m. 174344 Rossiyskaya Federatsiya, MPK B62D 55/00, B62D 65/02. Rama snegokhoda / A.M. Zhogin, YU.V. Barshchevskiy; zayavitel' i patentoobladatel' OOO "VELOMOTORS". - №2016150873; zayavl. 23.12.2016; opubl. 11.10.2017, Byul. № 29.

20. P. m. 176578 Rossiyskaya Federatsiya, MPK B62B 17/04, B62B 13/10, B62K 25/00. Podveska rulevoy lyzhi snegokhoda / R.S. Valeyev, A.A. Kudryavov, A.V. Maslov; zayavitel' i patentoobladatel' AO "Russkaya mekhanika". - №2017129040; zayavl. 14.08.2017; opubl. 23.01.2018, Byul. № 3 .

21. P. o. 107038 Rossiyskaya Federatsiya, MKPO 12-14. Snegokhod / A.A. Fabishevskiy, A.V. Sharshakov, P. Varotto; zayavitel' i patentoobladatel' OOO "Sanrayz". №2017501368; zayavl. 27.03.2017; opubl. 13.02.2018.

22. P. o. 104682 Rossiyskaya Federatsiya, MKPO 12-14. Snegokhod / R.S. Valeyev, A.V. Kamenskiy, A.V. Maslov; zayavitel' i patentoobladatel' AO "Russkaya mekhanika". №2016503093; zayavl. 09.08.2016; opubl. 16.08.2017.

23. Kotiev G.O., Diakov A.S. 2016. Method of developing the navigation systems of high mobility unmanned ground vehicles//News of southern Federal University. Engineering Science. T. 174(1): S. 186-197.

24. Kotiev G.O., Diakov A.S., Kartashov A.B., Padalkin B.V. Designs and development of Russian scientific schools in the field of cross-country ground vehicles building//ARPN Journal of Engineering and Applied Sciences. Vol. 12, no. 4, February 2017. pp. 1064-1071.

25. G. Kotiev, R. Zhirniy, A. Smirnov Technology of Wheeled Vehicles of High Passability on the Basis of Series Vehicles//Oboronnaya Tekhnika. 2011. Issue 2-3. pp. 75-79.

26. G. Kotiev, R. Zhirniy, A. Smirnov, V. Gorelov Researches of Cross-Country Vehicles in the Conditions of Far North//Gruzovik. 2010. Issue 12. pp. 34-37.

27. Kotiev G.O., Diakov A.S. Advanced development and testing of off-road vehicle // DEStech Transactions on COMPUTER SCIENCE and ENGINEERING. 2017 2nd International Conference on Computer, Mechatronics and Electronic Engineering (CMEE 2017) pp. 464-467. ISBN: 978-1-60595-532-2. DOI $10.12783 /$ dtcse/cmee2017/20021. 